\title{
Trestní odpovědnost zastupitelů měst a obcí
}

\section{Criminal Liability of Representatives of Cities and Municipalities}

\author{
Roman Vicherek ${ }^{*}$
}

\begin{abstract}
Abstrakt
Ve své clánku se hodlám věnovat trestni odpovédnosti ưrednich osob predevšm se zaměrením na členy zastupitelstev mèst a obci. Podrobnè se budu zabývat rizikey, která z výkonu této funkece plynou a okolnostem, kdy z. obavy tèchto osoby z prépináni trestni represe vedou k situaci, kdy se nedař̀ radu zastupitelstev prèedevšim $v$ menšich obcich a mèstech obsadit.
\end{abstract}

\section{Klíčová slova}

Trestni odpovédnost zastupitelù obcí; zneuřití pravomoci úredni osoby; porušeni povinnosti prù správé ciz̨ího majetku.

\begin{abstract}
In my article I intend to the criminal liability of officials mainly focused on members of councils of towns and villages. I will address in detail the risks that the performance of such duties arise and circumstances in which the concerns of the people from switching criminal repression leads to a situation where a series of councils are failing, especially in smaller towns and cities occupy.
\end{abstract}

\section{Keywords}

Criminal Liability of Representatives of Municipalities; Abuse of Powers of an Official Person; Violation of Obligations of Trust.

\section{Úvod}

V posledních několika letech jsme svědky zvýšeného počtu trestních stíhání na komunální úrovni, a to u zastupitelů měst a obcí, prrípadně radních či starostů. Je to tím, že by ze strany námi volených zástupců docházelo k častějšímu páchání trestné činnosti, či tento trend má jiné př́rciny?

Mezi zastupiteli řady měst a obcí mám své známé, jejich práce je pro obec důležitá, často časově náročná a nenahraditelná. Tyto osoby rozhodují o základních otázkách ř́zení a směřování jednotlivých obcí a měli by to být ti nejlepší z dané komunity obce či města, což je v zájmu všech občanů. Z jejích úst však často v poslední době slyším povzdech, že s přijetím funkcí v komunální politice pro ně rok od roku stoupá riziko, že při svém rozhodování a hlasování, se mohou ocitnout v hledáčku orgánů činných v trestním řízení. Důsledkem těchto skutečností je situace, kdy v řadě menší obci je problematické do zastupitelstva vůbec někoho ,dostat“.

\footnotetext{
* JUDr. Roman Vicherek, doktorand, Katedra trestního práva, Právnická fakulta Masarykovy univerzity, Brno / Ph.D. student, Department of Criminal Law, Faculty of Law, Masaryk University, Brno, Czech Republic / E-mail: vicherek@mail.muni.cz
} 
Odpovědnost zastupitelů by měla být především v rovině politické, trestní odpovědnost by s ohledem na zásadu subsidiaritu trestní represe a pojímání trestního práva jako ultima ratio, měl nastupovat vždy až jako poslední, pokud selžou všechny ostatní typy odpovědnosti - politické, občanskoprávní či správní mechanismy. V některých př́padech, které se $\mathrm{v}$ poslední době objevily v médiích, je to ale naopak a je na místě si klást otázku, zda se trestní odpovědnost nenadužívá.

Snaha zorientovat se v této problematice a poskytnou kvalifikovanou odpověd' na výše uvedené povzdechy zastupitelů, mne vedli ke snaze najít limity trestní odpovědnosti zastupitelů, ale neprrímo i rady či starostů, tedy osob činných ve volených orgánech územních samosprávných celků a pokusit se odlišit odpovědnost politickou od odpovědnosti trestně právní. Je nutné si odpovědět na otázku, zda jsou obavy zastupitelů ze vzrůstající trestní represe oprávněné či nikoliv. Nehodlám se zabývat celou šíři trestné činnosti páchanou zastupiteli, na to $\mathrm{v}$ této práci není dostatek prostoru, ale zaměřím se na nejspornější problematiku, související s hlasováním zastupitelů obcí především při rozhodování o nakládání s majetkem v samostatné působnosti obcí

Předmětná problematika trestního stíhání zastupitelů obcí však nezůstala toliko na komunální úrovni, ale vyvolala i spor, a z části odlišnou interpretaci zjištěných faktů, na celostátní úrovni a to mezi Nejvyšším státním zastupitelstvím, které zpracovalo a publikovalo 24. 9. 2014 pod sp. zn. 7NZN 603/2014 analýzu označen jako „Trestni odpovédnost osob činných ve volených orgánech územnich samosprávných celk:ü "1 a Unii obhájců České republiky, kteří publikovali ke dni 18. 3. 2015 „Stanovisko č.3/2015 k trestnímu stíhání zastupitelu měst a obci" ${ }^{2}$. Na názory obou stran tohoto sporů je nutné se podívat nestaranýma očima a vyvodit konkrétní závěry.

\section{Zastupitelé měst a obcí}

Dle \5 z.č. 128/2000 Sb. o obcích (obecní zrrízenî) je obec samostatně spravována zastupitelstvem obce, dalšími orgány obce jsou rada obce, starosta, obecní úrad a zvláštní orgány obce. Město je samostatně spravováno zastupitelstvem města, dalšími orgány města jsou rada města, starosta, městský úřad a zvláštní orgány města. ${ }^{3}$ Mandát člena zastupitelstva obce vzniká zvolením. Svůj mandát zastupitelé vykonávají osobně a v souladu se svým slibem a nejsou vázáni žádnými příkazy (〔 69 odst. 4 zákona o obcích).

1 Nejvy ̌̌si státni zastupitelstvi vydává analýz̨u k trestni odpovédnosti zastupitelu a radnich [online]. Publikováno 24. 9. 2014 [citováno 22. 2. 2016]. Dostupné z: <http://www.nsz.cz/index.php/cs/ aktuality/930-nejvyi-statni-zastupitelstvi-vydava-analyzu-k-trestni-odpovdnosti-zastupitel-a-radnich >".

2 Unie obhájců ČR. Stanovisko Unie obhájcu ČR č.3/2015 k. trestnímu stíhání quastupiteli mèst a obcí [online]. Publikováno 18. 3. 2015 [citováno 22. 2. 2016]. Dostupné z: <http://www.uocr.cz/wp-content/uploads/2015/04/ Stanovisko-Unie-obh $\%$ C3\%A1jc\%C5\%AF-\%C4\%8CR-\%C4\%8D-32015-k-trestn $\%$ C3\%ADmu-t $\%$ C3\%ADh $\%$ C3 $\%$ A 1 n $\%$ C3\%AD-zastupitel $\%$ C5\%AF-m $\%$ C4\% $\%$ Bst-a-obc $\% C 3 \% A D . p d f>$.

3 Pro účely tohoto článku se nebudu zabývat odlišnou úpravou pro statutární města vyplývající z $\int 5$ odst. 2, z.č. 128/2000 Sb. o obcích (obecní zřízení). 
Povinnosti zastupitelů obcí jsou upraveny především v zákonech:

- č. 128/2000 Sb., o obcích (obecní zřízenî),

- č. 89/2012 Sb., občanský zákoník,

- č. 159/2006 Sb., o střetu zájmů.

Další povinnosti poté stanoví, vyhlášky a nařízení obce, statuty obcí a usnesení zastupitelství a rad obcí.

Výslovně je upravena v zákoně č. 128/2000 Sb. povinnost zastupitelů účasti na zasedáních a plnění úkolio uložených obecními orgány (\$ 83 odst. 1) a dále povinnost oznámit střet zájmů (\83 odst. 2) Zastupiteli vymezuje povinnosti i složený slib dle \69 odst. 2, především povinnost vykonávat funkci svědomitě, v zájmu obce a jeho občanů a povinnost řídit se právními předpisy.

Ve vztahu k majetku obce, je nutné poukázat především na povinnost péče řádného hospodáře vyplývající z ustanovení \ 159 odst. 1 zákona č. 89/2012 Sb., ze kterého vyplývá, že: „Kdo prïme funkci člena voleného orgánu (tedy i zastupitel obce), zavazuje se, že ji bude vykonávat s nezbytnou loajalitou is potřebnými znalostmi a pečlivostí. Má se za to, že jedná nedbale, kdo neni této péče rádného hospodáre schopen, ač to musel zjistit prüprijetífunkce nebo pri jejím výkonu, a nevyvodí z toho pro sebe disledky.“" Zákon však nevyžaduje, aby každý byl odborníkem úplně na všechno, ale uplatňuje rozumnou zásadu, že pokud někdo něčemu nerozumí, musí si to uvědomit a obstarat si odborný posudek, aby mohl v dané věci rozhodnout. V poslední době právě s ohledem na porušení zásady péče řádného hospodáře stoupá trestní odpovědnost zastupitelů. ${ }^{4}$

Povinnosti zastupitelů ve vztahu k majetku obce dále upravuje zákon o obcích, ze kterého vyplývá, že majetek obce musi být vyư̌iván účelně a hospodáně v souladu s jejimi zájmy a úkoly vyplývajicimi ze zákonem vymezené puisobnosti. Obec je povinna pečovat o zachování a rozvoj svého majetku (\$38 odst. 1). Majetek obce musí být chráněn prè zničením, poškozenim, odcizenim nebo zneuřitim (\$38 odst. 2). Obec je povinna chránit svijj majetek pred neoprávnènými zásahy a včas uplatňovat právo na náhradu škody a právo na vydání bezdiovodného obohacení (\38 odst. 6).

Pokud jde o hlasování zastupitelů, pak se na ně nevztahuje dobrodiní imunity, jako na poslance či senátory ${ }^{5}$, ani institut souhlasu s trestním stíháním ze strany zastupitelstva, jichž jsou členy. Zastupitelé tedy musí pečlivě vážit každý důsledek svých projevu při zasedání zastupitelstva, včetně hlasování. Nemyslím si, že by bylo na místě nějakou formu imunity u zastupitelů zavádět. Poslanecká sněmovna je jednou ze složek zákonodárné moci

4 TOMAN, Petr. Trestněprávní odpovédnost zastupiteli I. [online]. Publikováno 15. 12. 2015 [citováno 22. 2. 2016]. Dostupné $\mathrm{z}$ : <http:// http://www.pravniprostor.cz/clanky/trestni-pravo/ trestnepravni-odpovednost-zastupitelu-i>.

5 Tyto podle článku 27 Ústavy ČR nelze postihnout za hlasování v Poslanecké sněmovně či Senátu nebo $\mathrm{v}$ jejich orgánech a trestně je nelze stíhat ani za projevy učiněné v obou komorách parlamentu a v jejich orgánech. 
a její imunita je exempcí z moci výkonné a soudní. Poslanecká imunita tedy zaručuje nezávislost poslanců (tedy části moci zákonodárné) na moci výkonné a soudní, a tudíž patřî do systému brzd a rovnovah. Tito mají imunitu pouze procesněprávní, tedy nemohou být stíháni klasickou cestou (nemohou být standardně stíháni mocí výkonnou a soudnî), ale musí je ke stíhání poslanecká sněmovna vydat. Členové parlamentu ale již nepožívajî imunitu hmotněprávní, to znamená, že nejsou vyjmuti z působnosti trestního zákona.

\section{Trestní odpovědnost}

Zastupitelé mohou páchat trestné činy s obecným subjektem, jako každá jiná fyzická osob, ty však nejsou obsahem mé práce, nebo trestné činy se speciálním subjektem, tedy ty trestné činy, kde vystupuji jako úřední osoby ve smyslu \ 127 trestního zákoníku (dř́ve veřejní činitelé podle $\int 89$ odst. 9 trestního zákona účinného do 31. 12. 2009). Z pohledu \127 odst. 1 písm. d) trestního zákoníku, jsou osoby činné ve volených orgánech územních samosprávných celků úředními osobami. Tohoto postavení však požívajî pouze, pokud plní úkoly státu nebo společnosti a používají při tom svěřené pravomoci pro plnění těchto úkolů. Dle $\int 127$ odst. 2 trestního zákoníku se k trestní odpovědnosti vyžaduje, aby trestný čin byl spáchán v souvislosti s její pravomocí a odpovědností.

Zastupitel obce, stejně jako i občan v běžném životě, musí nést odpovědnost za své jednání. Zůstává otázkou, v jaké rovině tato odpovědnost bude zakotvena, zda postačí odpovědnost občanskoprávní, odpovědnost správní či v př́ípadě zastupitele odpovědnost politická, nebo bude nutné prristoupit k odpovědnosti trestní. Pokud jde o hlasování na zastupitelstvu, principiálně by se mělo vycházet $z$ toho, že zastupitel hlasuje $\mathrm{v}$ zájmu obce, kterou platně ve spojení s ostatními zastupiteli na základě pověření voličů reprezentuje. Sám o ničem nerozhoduje, pouze ve spojitosti s ostatními zastupiteli rozhoduje jako kolektivní orgán obce - zastupitelstvo. Zastupitel hlasuje a teprve jeho prostřednictvím rozhoduje kolektivní orgán - zastupitelstvo. Jestliže převažují osobní zájmy zastupitele nad zájmy obce, respektive při hlasování zastupitel vědomě upřednostní své osobní zájmy, pak samozřejmě musí nést i případnou odpovědnost, a to i trestní.

Jedním z prvních rozhodnutí, které umožnilo trestního stíhání zastupitelů za hlasování v zastupitelstvu obce je rozhodnutí Ústavního soudu sp. zn. II. ÚS 265/07 ze dne 6. 6. 2007, ${ }^{6}$ ve kterém Ústavní soud konstatoval, že: „trestni stíhání bývalých či současných zastupiteli mèsta, členu jeho rady nebo dokonce starosty v souvislosti s hlasováním zastupitelstva o nakládání s majetkem města mĩ̌̌e mít nepřímý vliv na budoucí výkon samosprávy a zpuisob nakládáni s majetkem mèsta. To v̌̌ak nestač, aby tento orgán samosprávy


domáhat se zrušeni rozhodnuti v jejich trestnich vécech, zejména maji-li tyto osoby lepši a prímèjsí cestu k dosaženi tohoto cile a ke uplatnèni nastolené argumentace. "Tímto rozhodnutím Ústavní soud

6 Obdobně potom usnesení Ústavního soudu ČR ze dne 26. 6. 2008 pod sp. Zn. II. ÚS 653/07. 
připustil, že trestní stíhání zastupitelů v souvislosti s hlasováním zastupitelstva může mít nepřímý vliv na budoucí výkon samosprávy a způsob nakládání s majetkem města, avšak nevyvodil z toho žádné závěry ve vztahu k právu obcí na samosprávu. Tím akceptoval trestní stíhání minulých, současných i budoucích zastupitelů.

Pokud jde o individuální odpovědnost každého zastupitele za jeho hlasování v zastupitelstvu jako kolektivním orgánu, pak toto posvětil Nejvyšší soud ČR ve svém rozhodnutí ze dne 19.12. 2012 pod sp. zn. 5Tdo 827/2012, kdy uvedl: „Jestliže obvinéní jako členové zastupitelstva obce (mèsta) rozhodli na zasedáni tohoto vrcholnébo orgánu obce o schválení prodeje nemovitého majetku obce za podstatně nižši kupni cenu, nežjaká byla v daném mistě a čase dosažitelná (napr. za částku ve výši asi $1500000 \mathrm{Kčc}$ a ackeoli dosažitelná cena byla asi $5000000 \mathrm{Kč}$ ), lze v tomto jednáni spatrovat poruseni povinnosti prì opatrováni nebo správě cizího majetku vyplývajicí

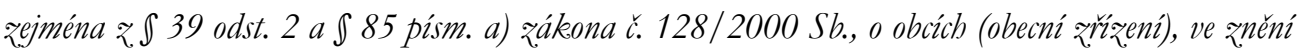
pozdějšich predpisu. Prĭtom význam rozhodováni členu zastupitelstva obce o prodeji nemovitého majetku obce a jejich postaveni odivodñuje i úvahu o tom, že pokud shora uvedeným zpuisobem porušili povinnost rádnè opatrovat nebo spravovat majetek obce, jde o porušeni dùležité povinnosti ve smyslu \255a odst. 1


tr. zák., \16 odst. 1 pism. al, odst. 2 tr. zákoniku) by zde bylo možné dovodit u členu zastupitelstva obce mimo jiné z. toho, že na zasedáni zastupitelstva obce, na nèmž se rozhodovalo o schváleni prodeje nemovitého majetku obce, byli upozornèni jinými členy zastupitelstva obce na určité skutečnosti, z.nichž. vyplývá možnost príliš niqké kupni ceny a které védomě pominuli. Trestní odpovědnosti každého z členů zastupitelstva obce, který hlasoval pro schválení nevýhodného prodeje nemovitého majetku obce, pak nebrání ani skutečnost, jestliže rozhodoval jako člen kolektivního orgánu obce. Ke schváleni prodeje nemovitého majetku obce se totiž vyžaduje soublas nadpolovični vétšiny v̌̌ech členu zastupitelstva obce (I 87 zákona o obcích), takeže všichni členové zastupitelstva predstavujici tuto vètšinu, bylo-li ji dosaženo, se bezprostrednè podileli na prijetí takového rozhodnuti zastupitelstva obce, pričemž každý z nich mèl stejný blas. Proto i trestni odpovèdnost za schváleni a düsledky rozhodnuti prijatébo zminènou vètšnou, pokud bylo učinèno v rozporu s povinností členu zastupitelstva obce rádné spravovat majetek obce (』38 a násl. qákona o obcích), mohou nést všichni členové zastupitelstva obce, kteří hlasovali pro schválení určitého rozhodnutí, jímž byla zpưsobena škoda na majetku obce. "

Z výše uvedených rozhodnutí je tedy možné dospět k závěru, že judikatura umožn̆uje trestní stíhání zastupitelů obce v souvislosti s hlasováním v zastupitelstvu, kdy lze dovodit individuální odpovědnost každého konkrétního zastupitele.

Pokud pomineme trestnou činnost související s korupcí, jejîž trestnost nevzbuzuje závažnější výkladové problémy, pak se u zastupitelů při rozhodování o majetku obce jedná především o trestní stíhání pro tyto trestný činy:

- zneužití pravomoci úřední osoby podle \329 trestního zákoníku,

- porušení povinnosti při správě cizího majetku podle \220 trestního zákoníku. 
Jednání zastupitelů bývá posuzováno i podle jiných ustanovení trestního zákoníku, těmito se však nebudu ve svém př́spěvku zabývat.

\section{- $\$ 329$ zneužití pravomoci úřední osoby}

Předmětná skutková podstata je naplněná tím, že úřední osoba, keterá v úmyslu zpiosobit jinému škodu nebo jinou závažnou újmu anebo opatrìt sobě nebo jinému neoprávnèný prospèch a) vykonává svou pravomoc zpiisobem odporujicim jinému právnimu predpisu, b) prekeroči svou pravomoc, nebo c) nesplni povinnost vyplývajici z jeji pravomoci, bude potrestána odnètím svobody na jeden rok ažpèt let nebo zákazem činnosti.

Musí se jednat o úmyslný trestný čin, kdy je nutné prokázat, že úřední osoba (speciální subjekt, kterým zastupitel je) při výkonu svých pravomocí měl úmysl způsobit jinému škodu nebo jinou vážnou újmu nebo opatřit sobě nebo jinému neoprávněný prospěch. Jestliže tyto dvě podmínky prokázány nejsou, tak i v prŕpadě, že dojde k porušení pravomoci či nesplnění povinnosti vyplývající z pravomoci, bude na uvedené pohlíženo jako na krok způsobený z neznalosti a nebude se tudíž jednat o trestný čin. ${ }^{7}$

Předmětný trestný čin má i svou nedbalostí variantu v ustanovení \330 trestního zákoníku, nicméně z praxe jsem nezaznamenal žádný př́ípad, který by byl takto kvalifikován. Shodný názor má i Jan Sváček předseda Vrchního soudu v Praze. ${ }^{8}$

\section{- \220 porušení povinnosti při správě cizího majetku}

Z \220 trestního zákoníku vyplývá, že: „Kdo poruši podle zákona mu ulo ̌̌enou nebo smluvně prevzatou povinnost opatrovat nebo spravovat cizi majetek, a tím jinému zpisobi škodu nikoli malou, bude potrestán odnétím svobody až na dvè léta nebo zákažem činnosti."

U tohoto trestného činu jde nejen o porušení zákona, ale i o porušení smluvně převzaté povinnosti, to znamená povinnosti převzaté z titulu výkonu své funkce, tedy i z titulu príjetí funkce v zastupitelstvu obce. I zde je podmínkou způsobení škody, a to škody toliko nikoliv malé. Tedy škody ve výši pouhých 25000 Kč. Tato hranice se jeví jako poměrně nízká, kdy zastupitelstva obcí jednají převážně o případech, kdy dopady jsou výrazně vyšší. I u této skutkové podstaty je vyžadován úmysl, musí tedy být prokázáno, že zastupitel, chtěl způsobit škodu nebo minimálně byl s možným způsobením škody srozuměn.

I u této skutkové podstaty upravuje trestní zákoník nedbalostní variantu a to v ustanovení \221 která je následujícího znění: „Kdo z. hrubé nedbalosti poruši podle zákona mu uloženou nebo smluvně prevaatou dìležitou povinnost prí opatrováni nebo správě ciz̨ího majetku, a tím jinému zpuisobi značnou škodu. "Jinými slovy to znamená, že zastupitel si ani nemusel být vědom skutečnosti, že svou povinnost může porušit.

7 TOMAN, Petr. Trestněprávní odpovédnost zastupiteli I. [online]. Publikováno 15. 12.2015 [citováno 22. 2. 2016]. Dostupné z: <http://www.pravniprostor.cz/clanky/trestni-pravo/ trestnepravni-odpovednost-zastupitelu-i>.

8 SVÁČEK, Jan. Roz̧̧odování zastupiteli neni jen o ceně, ale $i$ o politice a etice [online]. Publikováno 22. 7. 2014 [citováno 22. 2. 2016]. Dostupné z: <http://www.ceska-justice.cz/2014/07/ jan-svacek-rozhodovani-zastupitelu-neni-jen-o-cene-ale-i-o-politice-a-etice/ $>$. 
Postačí, že uvedené teoreticky vědět měl a mohl. V případě nedbalostní varianty je vyžadováno způsobení škody značné, tedy škody minimálně ve výši 500000 Kč.

\section{Problematická místa trestněprávní kvalifikace:}

- vznik škody $x$ veřejný zájem obce

Škoda se chápe jako újma, která nastala v majetkové sféře poškozeného a je objektivně vyjádřitelná v penězích. Skutečnou škodou u výše uvedené trestné činnosti se pak rozumí jakékoli zmenšení hodnoty opatrovaného nebo spravovaného majetku, k němuž by nedošlo, kdyby byl majetek spravován nebo opatrován řádně. Škodu lze mj. spatřovat i v př́padě, jestliže při dispozici se spravovaným nebo opatrovaným majetkem pachatel $\mathrm{v}$ důsledku porušení povinnosti neobdrží za jeho zcizení (nebo za zcizení jeho části) odpovídající protihodnotu, kterou by jinak bylo možno získat. V př́padě obce, na rozdíl od podnikatelských subjektů, jejichž účelem je dosažení zisku, není a nemůže být zisk jediným kritériem, na základě kterého by se zastupitelstva obce měla rozhodovat. Prioritní by pro zastupitelstvo obce měl být především zájem občanů obce a péče o obec jako takovou, především o její rozvoj a prosazení obecného zájmu. Obec je povinná pečovat o všestranný rozvoj svého území a o potřeby svých občanů. Při plnění svých úkolů obec chrání též veřejný zájem ( 2 odst. 2 zákona o obcích) a vytváří podmínky pro rozvoj sociální péče a pro uspokojování potřeb svých občanů, dostatečně vhodným, místním poměrům a zvyklostem přiměřeným způsobem ( $\int 35$ odst. 2 zákona o obcích).

Pokud jde o otázku vzniku škody z jednání obce (konkrétně starosty obce), pak lze poukázat na rozhodnutí Nejvyššího soudu sp. zn. 5 Tdo 273/2014 ze dne 16. 7. 2014, který uvedl: „Prestože cena stanovená společností P.H. byla o 35 milionư vy̌̌ší, na čemž dogmaticky dovolatel (NSZ) stavi své turzeni o vzniku škody ve formě majetkové újmy, ve skutečnosti se její úhrada jevila nejistou, a to nejen ve svém rozsahu, ale dokonce budoucí možná neshoda stran na jejím snížení mohla pro kupujícího znamenat právo odstoupení od smlouvy. Proto je nutné odmitnout názor nejvy šsího státního zástupce o poškozeni mèsta N. výbèrem kupujicího, který byl ochoten, (a také tak následnè fakticky učinil), zaplatit za akcie cenu sice nižšr, ale bezprostrèdnè po uzavreni smlouvy bezjakýchkoli podminek. Nabidka společnosti PH byla pro prodávajicího natolik riskantni v mo:̌nyich disledcich, a to s obledem na dobu splatnosti, ale predev̌̌im na naprosto neprédvidatelný a pro mèsto $N$. dokonce neovlivnitelný vývoj (fakticky nesmèlo vykonávat akcionárská práva), že rozumně uvažujici osoba by na ni nepristoupila. $Z$ toboto pobledu neni mo:̌né vyčitat výbèrové komisi a členùm obou orgánù mèsta i obvinènému, že pri výbèru vhodného smluvního partnera na odkoupeni akcii PN, a. s., považovali za pro mèsto výhodnèjš́ a lepšsi nabidku obchodni společnosti L, a. s. "

Veřejný zájem občanů obce a obce samotné nevede vždy k maximalizaci zisku či finančního prospěchu obce. Představme si situaci, kdy zastupitelstvo rozhoduje o směně pozemků, která z účetního hlediska způsobí obci ztrátu. Obec totiž smění pozemek s vyšší účetní hodnotou za pozemek s nižší účetní hodnotou, nicméně

9 ŠÁMAL, Pavel a kol. Trestní zákonik - Komentár. 2. vyd. Praha: C. H. Beck, 2012, s. 2185-2186. 
tato směna umožní obci vybudovat obchvat obce, který povede jednak ke zlepšení dopravní situace v obci, jakož i ke zlepšení životního prostředí. Mám za to, že takové jednání je $\mathrm{v}$ zájmu obce a zastupitelstvo by jej mělo realizovat, přestože na první pohled se může zdát, že zastupitelstvo obce pochybilo. Tento zjednodušující pohled na transakce obce, kdy není cílem transakce dosažení maximálního zisku, ale veřejný zájem, vede často orgány činné v trestním řízení ke zjednodušenému pohledu na věc a stíhání zastupitelů. Je totiž snazší vyjít z účetní hodnoty směněných pozemků, zjištěných prípadně znaleckým posudkem než se zabývat otázkou veřejného zájmu obce, která je orgánům činným v trestním řízení zcela cizí. Nicméně je nutné se vyvarovat mechanického posuzování znaků objektivní stránky trestného činu, je nutné proniknout do hloubky problematiky a konkrétní věc posuzovat komplexně ze všech úhlů.

Shodně se vyjadřuje i Nejvyšší státní zástupce Pavel Zeman když upozorňuje, že ekonomická výhodnost prodeje nemovitostí obcí či jejich majetkových převodů nesmí být jediným hlediskem, podle něhož je státní zástupce hodnotí. Nízká cena totiž může být vysvětlena tím, že obec získá od kupce jinou výhodu, např́iklad kupec slíbí dekontaminaci znečištěných pozemků, které mu obecní či městská samospráva výhodně prodá. ${ }^{10}$

Na výše uvedený prrípad dopadá i zákonné ustanovení a to \39 odst. 2 zákonu o obcích, dle kterého platí, že „prí úplatném prevodu majetku se cena sjednává zpravidla ve výsí, která je v daném mistě a čase obvyklá, nejde-li o cenu regulovanou státem. Odchylka od ceny obvyklé musí být zdůvodněna.". Ekonomická výhodnost dispozičních operací s majetkem obce (koupě, prodej, směna apod.) je prvotním hlediskem, avšak není a ani nemůže toto být hlediskem jediným. Zákon o obcích umožňuje odchýlit se od této ekonomické výhodnosti dispoziční operace, ale jen, když je taková odchylka důvodná. Což znamená, že tato odchylka musí být založena na legitimních, objektivních důvodech, a současně tyto důvody musí být prokazatelným způsobem zaznamenány v rozhodnutí orgánu obce. Zde lze odkázat např. na rozsudek Nejvyššího soudu sp. zn. 28 Cdo 3950/2010, podle kterého je: „Smlowva o úplatném prevodu obecního majetku za cenu podstatně nižší, ně̌je cena v mistě

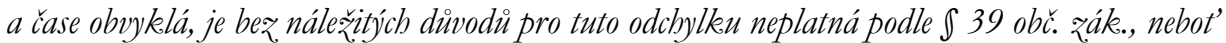

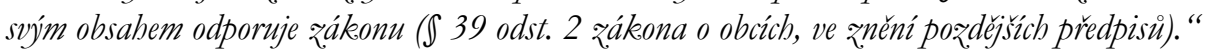

Ustanovení \39 odst. 2 zákona o obcích umožňuje dospět obci i k odlišnému závěru při převodu obecního majetku (nepůjde o maximalizaci zisku), pokud bude odchylka zdůvodněná, tedy bude mít legitimní základ v plnění úkolů obce v samostatné působnosti dle $\int 38$ odst. 1 zákona o obcích. Právě posuzování těchto odchylek, pak činí orgánům činným v trestním řízení značné potíže, kdy je nutno vyhodnotit i další relevantní údaje a není možné vyjít jen z jednoduchého porovnání cen (v tomto př́padě zisku pro obec).

10 ZEMAN, Pavel. Zastupitelé a radni netrpi premírou trestni represe [online]. Publikováno 24. 9. 2014 [citováno 22. 2. 2016]. Dostupné z: <http://www.ceska-justice.cz/2014/09/ pavel-zeman-zastupitele-a-radni-netrpi-premirou-trestni-represe/ $>$. 


\section{- subjektivní stránka}

Je nutné si uvědomit, že v ČR je v současné době něco okolo 60.000 zastupitelů, ne všichni jsou právníci či specialisté na trestní právo. Každý zastupitel není, a ani nemůže být, odborníkem na každou oblast správy obce, o které hlasují. Zastupitelé často rozhodují bud' na zásadě své vlastní, nedostatečně hluboké a kvalitní analýzy problematiky, která však není v množství a složitosti řešených problémů obce často možná, nebo na základě podkladů vypracovaných jinými osobami, tedy osobami znalými dané problematiky. Zastupitelé poté hlasují na základě podkladů zpracovaných odbornými zaměstnanci obcí, popř. dokonce na základě právních stanovisek advokátních kanceláŕi či znaleckých posudků Pokud takové stanovisko nebo zpracované podklady prijetí rozhodnutí doporučují a zastupitel nemůže v rámci svých znalostí rozpoznat, že se jedná o doporučení nesprávné, těžko lze dovodit úmysl zastupitele způsobit obci škodu a trestní postih by měl být v takovém príipadě vyloučen, protože bude chybět subjektivní stránka trestného činu.

Existují i případy, kdy PČR stíhala starostu obce, který rozhodl o nakládání s majetkem obce za cenu dle znaleckého posudku, avšak byli následně trestně stíháni proto, že znalec jmenovaný policií dospěl k odlišné ceně (rozhodnutí Nejvyššího soudu sp. zn. 5 Tdo $273 / 2014$ ze dne 16. 7. 2014). Často si poté zastupitele kladli otázku, kolik znaleckých či právních posudků musí před svým rozhodnutím mít, aby se vyhnuli nebezpečí trestního stíhání, a poukazovali na príklady, v nichž ani dva posudky nepostačovaly, nebot' si policie obstarala další posudek, který dospěl k odlišnému závěru než jejich znalci. ${ }^{11}$

$\mathrm{Na}$ tuto skutečnost však reagoval i Nejvyšší soud v rozhodnutí sp. zn. 5 Tdo 848/2010 ze dne 19. 1. 2011 kdy uvedl: "Jestliže laické osoby se spolehnou na informace advokáta, jako osoby práva znalé, aniž by měly nějaké věrohodné signály, $z$ nichž by mohly dovodit nesprávnost takových informací, nelze u nich zpravidla dovodit úmyslné zavinění ve væ̧tahu k v₹niku tvrzené šody na podkladè jejich jednání v právním smyslu. "Pokud se tedy zastupitelé jako právní laici spolehnou na informace advokáta, ale mám zato, že i dalších odborníků napríiklad znalců, jako osob problematiky znalé, aniž by měly nějaké věrohodné signály, z nichž by mohly dovodit nesprávnost jim poskytnutých informací, pak u nich zpravidla nelze dovodit úmyslné zavinění ve vztahu k vzniku tvrzené škody na podkladě jejich jednání. Ačkoliv se judikát týká pouze úmyslného zavinění, mám za to, že lze vztáhnout i na zavinění nedbalostní.

NSZ se ve své analýze pokusilo ve vztahu k subjektivní stránce trestného činu vymezit skutečnosti, které nejčastěji vedli k spáchání některého z výše uvedených trestných činů z vědomé, resp. nyní hrubé nedbalosti.

11 Unie obhájců ČR. Stanovisko Unie obhájců ČR č. 3/2015 k trestnímu stíhání zastupitelu měst a obcí [online]. Publikováno 18. 3. 2015 [citováno 22. 2. 2016]. Dostupné z: <http://www.uocr.cz/wp-content/ uploads/2015/04/Stanovisko-Unie-obh $\%$ C3\%A1jc\%C5\%AF-\%C4\%8CR-\%C4\%8D-32015-k-

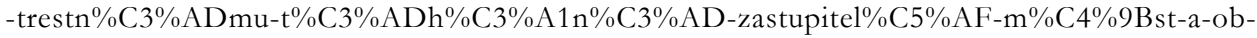
c $\%$ C $3 \%$ AD.pdf $>$. 
- Člen nebo členové byli př́tomni na zasedání zastupitelstva rozhodného dne.

- V rozhodný den na zasedání zastupitelstva předmětem jednání bylo rozhodování o prodeji předmětného nemovitého majetku obce.

- Členové zastupitelstva prítomní na uvedeném zasedání zastupitelstva byli upozorněni (např. jinými členy zastupitelstva) na skutečnosti, z nichž vyplývá možnost príliš nízké ceny, za kterou se navrhuje nemovitost prodat.

- Členové upozornění na možnou př́liš nízkou cenu pominuli.

- Členové na zasedání zastupitelstva přes uvedené upozornění hlasovali pro schválení nevýhodného prodeje nemovitého majetku obce.

- Usnesení o schválení nevýhodného prodeje nemovitého majetku obce bylo přijato nadpoloviční většinou všech členů zastupitelstva obce ( $(87 \mathrm{OZ})$, takže uvedená většina členů zastupitelstva se bezprostředně podílela na přijetí tohoto rozhodnutí zastupitelstva, přičemž každý z jeho členů měl stejný hlas. ${ }^{12}$

\section{Statistika}

Ministerstvo spravedlnosti ani justice nevedou žádné relevantní statistiky, které by nám mohli dát informaci, zda a jak často jsou stíhání zastupitelé obcí. Je možné dohledat dva prameny, které pracují se statistikami z této oblasti, a to již výše zmiňovaná analýza Nejvyššího státního zastupitelství, publikována 24. 9. 2014 pod sp. zn. 7NZN 603/2014 označená jako „Trestni odpovédnost osob cinnyich ve volenjich orgánech üzemnich samosprávných celkư`‘3 a stanovisko Unie obhájců České republiky, publikované 18. 3. 2015 pod názvem

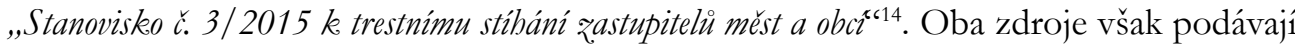
dosti odlišné informace.

NSZ pracovalo jednak s rozhodnutími Nejvyššího soudu v rámci dovolání, jednak s př́ipady vedenými u NSZ. Z této statistiky vyplývá, že od roku 2008 do záŕí 2014 došlo k 22 rozhodnutím Nejvyššího soudu, kdy bylo vedeno řízení s 24 zastupiteli (z toho s 23 zastupiteli v jedné věci). Jen v 11 prípadech se jednání týkalo nakládání s majetkem, z toho v 9 prŕpadech s nakládání majetkem bez souhlasu rady nebo zastupitelstva. NSZ bylo činné v 15 věcech. Obviněno v těchto věcích bylo 15 zastupitelů, 5 prípadů se tý-

12 Nejvy̌šri státní zastupitelstvi vydává analýzu ke trestni odpovédnosti zastupiteli a radnich [online]. Publikováno 24. 9. 2014 [citováno 22. 2. 2016]. Dostupné z: <http://www.nsz.cz/index.php/cs/ aktuality/930-nejvyi-statni-zastupitelstvi-vydava-analyzu-k-trestni-odpovdnosti-zastupitel-a-radnich> .

13 Tamtéž.

14 Unie obhájců ČR. Stanovisko Unie obbajjcu ČR č.3/2015 k trestnímu stíhání zastupitelů mèst a obcí [online]. Publikováno 18. 3. 2015 [citováno 22. 2. 2016]. Dostupné z: <http://www.uocr.cz/wp-content/ uploads /2015/04/Stanovisko-Unie-obh $\%$ C3\%A1jc\%C5\%AF-\%C4\%8CR-\%C4\%8D-32015-k-trestn $\% \mathrm{C} 3 \% \mathrm{ADmu}-\mathrm{t} \% \mathrm{C} 3 \% \mathrm{ADh} \% \mathrm{C} 3 \% \mathrm{~A} 1 \mathrm{n} \% \mathrm{C} 3 \% \mathrm{AD}$-zastupitel $\% \mathrm{C} 5 \% \mathrm{AF}-\mathrm{m} \% \mathrm{C} 4 \% 9 \mathrm{Bst}$-a-ob$\mathrm{c} \% \mathrm{C} 3 \% \mathrm{AD} \cdot \mathrm{pdf}>$. 
kalo nakládání s majetkem, z toho 4 prípady byly nakládání s majetkem bez souhlasu zastupitelstva nebo rady. ${ }^{15}$

Naopak ze stanoviska Unie obhájců České republiky vyplývá, že v letech 1995 až 2014 bylo vedeno 75 trestních řízení proti 266 zastupitelům. Oproti analýze NSZ zmapovali navíc 38 prrípadů. V 29 trestních rrízeních bylo jednání zastupitelů kvalifikováno bud' samostatně, nebo v souběhu s trestným činem zneužití pravomoci úřední osoby, jako porušení povinnosti při správě cizího majetku (\220 a \221 TZ, 』255 TrZ), v 51 trestních řízeních bylo kvalifikováno jednání zastupitelů jako zneužití pravomoci úŕední osoby (\$ 158 TrZ, \329 TZ), v 9 trestních ř́zeních bylo kvalifikováno jednání zastupitelů jako pŕijetí úplatku (\160 TrZ, \331 TZ), v 31 trestních řízení byla užita jiná právní kvalifikace.

K 28. 2. 2015 bylo pravomocně ukončeno 43 trestních řízení proti 100 zastupitelům. Z tohoto počtu bylo 19 trestních řízení ukončeno výrokem o vině obžalovaného zastupitele. Zbývajících 24 trestních řízení bylo ukončeno jinak (5 trestních řízení ukončeno státním zástupcem - 2x zastaveno, 3x zrušeno usnesení o zahájení trestního stíhání, 17 trestních řízení ukončeno zproštěním obžaloby soudem). V jednom př́padě bylo ukončeno jak zproštěním obžaloby soudem, tak i výrokem o vině. $V$ jednom př́padě bylo ukončeno zproštěním obžaloby soudem, tak i zastavením trestního stíhání SZ, to znamená, že 58 \% trestních řízení, která již byla pravomocně ukončena, bylo zahájeno, resp. vedeno nezákonně. Odečteme-li prípady trestních řízení, v nichž byl obsažen korupční prvek (celkem 6 trestních řízení, z nichž 5 skončilo výrokem o vině a jeden zproštěním obžaloby), pak je toto číslo ještě vyšší: 65 \% trestních řízení, která již byla pravomocně ukončena, a nebyl v nich obsažen korupční prvek, bylo zahájeno, resp. vedeno nezákonně.

Rozdíly v obou statistikách vyplývají z jejich záběru. Data poskytnuté Unií obhájců ČR jsou za delší časové období od roku 1995 do 28. 5. 2015, zatímco data NSZ jsou poskytována za období od 2008 do zárí 2014. Navíc NSZ vycházelo jen z omezeného množství dat, ke kterým mělo přístup přes své databáze (nevycházelo s dat OSZ a KSZ), oproti tomu Unie obhájců se pokusila postihnout celé spektrum těchto případů, kriticky je však nutné uvést, že Unie obhájců nemá prostředky k objektivnímu zkoumání, kdy vychází toliko z dat poskytnutých svými členy. Je tedy reálné, že těchto př́pado̊ bude výrazně více a čísla poskytnutá Unií obhájců ČR mưžeme považovat za minimální.

V České republice je v současné době přibližně 6200 obcí, ve kterých působí přibližně 60.000 zastupitelů. Pokud zohledníme funkční období zastupitelstva, tak z předmětných čísel je patrné, že trestně stíháno v letech 1995 - 2014 bylo méně než $0,1 \%$ zastupitelů. Celkový počet stíhaných zastupitelů pak, dle mého názoru, není nijak enormní, spíše

15 Nejvy šsi státni zastupitelstvi vydává analýzu k trestni odpovédnosti zastupitelu a radních [online]. Publikováno 24. 9. 2014 [citováno 22. 2. 2016]. Dostupné z: <http://www.nsz.cz/index.php/cs/ aktuality/930-nejvyi-statni-zastupitelstvi-vydava-analyzu-k-trestni-odpovdnosti-zastupitel-a-radnich>. 
naopak. Nicméně to co vzbuzuje obavu, je především nastolený trend. Od roku 2010 dochází nejen k zvýšení počtu trestních stíhání o cca 200\% v roce 2013, ale především počtu stíhaných zastupitelů a to o $1.560 \%$. Pořád však jde o trestní stíhání toliko o $0,5 \%$ všech zastupitelů v současném volebním období. Navíc je nutné konstatovat, že v roce 2014 se růst zastavil. Výrazné zvýšení počtu stíhaných zastupitelů od roku 2013, oproti mírnějšímu nárůstu počtu trestních stíhání v dřívějších letech pak pravděpodobně souvisí s rozhodnutím Nejvyššího soud ČR ze dne 19. 12. 2012 pod sp. zn. 5Tdo 827/2012, kterým Nejvyšší soud potvrdil individuální odpovědnost každého zastupitele za jeho hlasování v zastupitelstvu. Druhou nepříznivou informací je skutečnost, že PČR se nedaří tuto problematiku úspěšně řešit, naopak $58 \%$ trestních řízení, která již byla pravomocně ukončena ( $65 \%$ bez případů s korupčním prvkem), bylo zahájeno, resp. vedeno nezákonně. Je nutné zvýšit dohled nad PČR a tuto př́padně vést $\mathrm{k}$ tomu, aby počet obviněných a odsouzených osob nebyl tak diametrálně odlišný. Jsou zde patrné zjevné tendence k přepínání trestní represe tam, kde to není na místě.

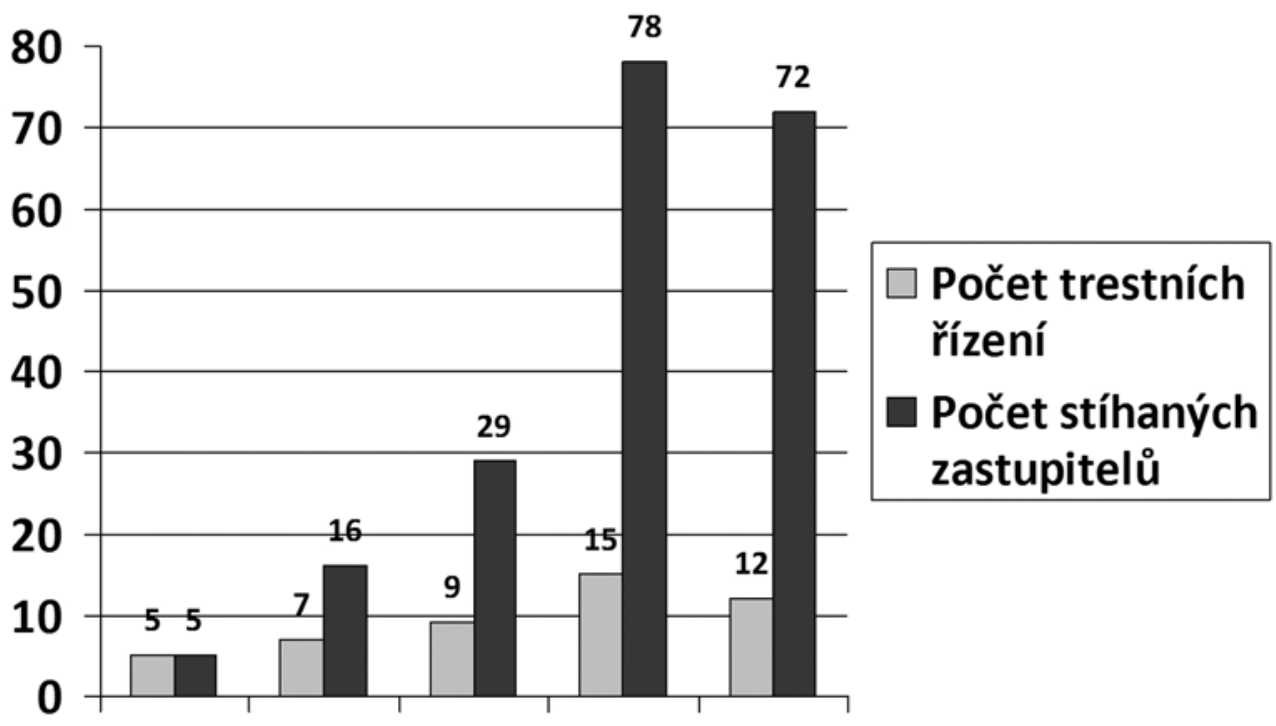

\section{$201020112012 \quad 2013 \quad 2014$}

Zdroj: autor

\section{Opatření k minimalizaci rizika členů zastupitelstva}

Povinnost zastupitele vykonávat svou funkci s péčí řádného hospodáře, neznamená, jak jsem rozvedl výše, že by tuto funkci nemohl vykonávat ten, kdo není odborníkem v záležitostech, o nichž má rozhodovat. Platí, že zastupitel by neměl rozhodovat bez znalosti věci, kterou bud’ může mít sám ze své vlastní zkušenosti, nebo ji může získat obvykle 
na základě podkladů, získaných od obce na základě podkladových materiálů pro jednání zastupitelstva. Pokud dostatečné podklady pro to, aby se mohl rozhodnout se znalostí věci, nemá, měl by se zdržet hlasování a požadovat jejich doplnění. Současně ale platí, že pokud se zastupitel spolehne na informace, které mu sama obec pro účely rozhodování předala, nelze mu klást $\mathbf{k}$ tíži, že se tyto materiály ukázaly jako chybné a že se jimi tento zastupitel ř́dil, pokud tyto materiály nevzbuzovaly pochybnost o své správnosti či kvalitě.

Doporučení, která mohou vést ke snížení rizika trestní odpovědnosti zastupitele, jsou následující:

1. Vzdělávání zastupitelů, především v oblasti právní úpravy, zejména v oblasti nakládáním s majetkem obce.

2. Dodržovat nejen všechny zákony, ale i vyhlášky a usnesení.

3. Dostatečně připravené podklady pro rozhodování zastupitelstva odborným aparátem obce, nebo odborníkem, prípadně pokud podklady nebudou dostačující, je nutné požadovat doplnění těchto podkladů.

4. Podrobné vedení zápisů z jednání zastupitelstva, pro zdůvodnění způsobu a důvodu rozhodnutí zastupitelů, včetně podkladů ze kterých při svém rozhodování vycházeli.

5. Odůvodňovat všechna rozhodnutí, především s ohledem na \39 zákona o obcích. S odstupem času pak bude možné dovodit, jakými důvody byli zastupitelé vedeni.

6. Veškeré rozhodnutí zveřejnit, v řadě trestních řízení otázka zveřejnění byla následně soudem vyhodnocena tak, že nebylo cílem někoho poškodit, zejména ne obec. ${ }^{16}$

\section{Závěry}

Možnost trestního stíhání zastupitele za jeho hlasování je bezesporu významnou skutečností pro ty, kteří by chtěli vykonávat tuto veřejnou funkci. Zvyšuje se tak míra nároků kladená na výkon funkce zastupitelů. Zastupitelé nechrání oproti poslancům imunita, což je však správně a nemyslím si, že by bylo nutné tuto skutečnost jakkoliv měnit. Tato situace klade zvýšené nároky na zastupitele, kteří si budou muset doplnit znalosti zákonů a dalších právních předpisů, vztahujících se ke správě a řízení obce. Zvýšení odbornosti či kvalifikace zastupitelů jistě nebude na škodu, pokud rozhodují o základních otázkách správy obce. Bude nutné, aby zastupitelé věnovali zvýšenou pozornost jednotlivým rozhodnutím a prrípravě na jednání, včetně zajištění dostatečného množství informací pro jejich rozhodnutí. Pokud je nedostanou, je na místě se zdržet hlasování a požádat o jejich doplnění, byt' to může mít za následek zvýšené náklady obce na stanoviska advokátů či znalecké posudky. Při rozhodování bude nutné postupovat s péči ráádného hospodáře, nicméně při zohlednění veřejných zájmu obce. Každé rozhodnutí zastupitelů

16 Obec např́iklad údajně špatně prodala pozemky, ovšem o svém postupu neustále informovala veřejnost, takže o prodeji všichni věděli a nikdo proti němu neprotestoval. 
pak bude nutné podrobně odůvodnit, především se zaměřením na odchylky dle $\ 39$ odst. 2 zákona o obcích. Jednání zastupitelstva by mělo být transparentní a rozhodnutí zveřejňována.

Závěrem bych chtěl uvést, že se neztotožňuji se závěry Unie obhájců ČR, ale ani se závěry analýzy NSZ. Faktem je to, že počet trestních řízení, zjištěných Unii obhájcủ ČR se zastupiteli od roku 2010 postupně stoupal až do roku 2013, nicméně nijak zásadně (5 trestních ř́zení v roce 2010 a 15 trestních rízení v roce 2013). V roce 2013 se trend zastavil a obrátil (12 trestních řízení v roce 2014). Pokud výrazně vzrostl počet stíhaných zastupitelů v roce 2013 - 78 osob a v roce 2014 - 72 osob, pak dle mého názoru tato skutečnost pravděpodobně souvisí s rozhodnutím Nejvyššího soud ČR ze dne 19. 12. 2012 pod sp. zn. 5Tdo 827/2012, kterým potvrdil Nejvyšší soud ČR individuální odpovědnost každého zastupitele za jeho hlasování v zastupitelstvu. I zde došlo v roce 2014 ke stabilizaci. Když zohledníme skutečnost, že v ČR je okolo 60.000 zastupitelů pak jde pořád jen o desetiny procent stíhaných zastupitelů. Nemyslím si tedy, že by se PČR na zastupitele zaměrila a že by docházelo ze strany těchto orgánů $\mathrm{k}$ neoprávněným zásahům do samosprávy obcí. Na druhou stranu je nutné připustit, a toto jako problém vnímám, že počet stíhaných a počet odsouzených zastupitelů je velmi rozdílný, tedy, že velká část trestních stíhání proti zastupitelům končí zprošt’ujícími výroky soudu, což ve svém důsledku k přepínání trestní represe vede. Alarmující jsou čísla zveřejněné Unii obhájcủ ČR kdy $65 \%$ př́padů (bez př́padů s korupčním prvkem), bylo zahájeno, resp. vedeno nezákonně. Je nutné, aby se PČR podrobněji a pečlivěji zabývala každým př́padem individuálně, především se zaměřením na výše uvedená problematická místa právní kvalifikace (otázka vzniku škody x veřejný zájem obce, subjektivní stránka trestného činu) a nesnažila se volit myšlenkové zkratky a mechanicky stíhat zastupitelé. Současně je nutné, aby byla ze strany PČR aplikována výše uvedená judikatura.

Mám za to, že právní úprava, doplněná judikaturou je u trestné činnosti zastupitelů nastavená správně. Postupem času vyšší soudní instance upřesní svými rozhodnutími výklad sporných otázek a PČR se těmto rozhodnutím přizpůsobí. Na druhou stranu zde budeme mít i vzdělanější a pečlivější zastupitelé obcí, kteří budou vyžadovat podrobnější informace ke svým rozhodnutím, a jejich rozhodnutí bude mít vyšší úroveň. 